\title{
Reporting social behaviours of mixed-species troops formed by Callithrix jacchus and Callithrix penicillata (Primate, Callitrichidae)
}

\author{
Valença-Silva, G. ${ }^{a *}$, Maciel, FG. ${ }^{b}$, Zaganini, RL. ${ }^{c}$, Lucindo, $A S .{ }^{d}$, \\ Caramaschi, S.e and Paula, HMG. de (in memoriam) ${ }^{b}$ \\ ${ }^{a}$ Departamento de Fisiologia, Instituto de Biociências, Universidade Estadual Paulista - UNESP, \\ Distrito de Rubião Júnior, CP 510, CEP 18618-970, Botucatu, SP, Brazil \\ ${ }^{\text {b} C e n t r o ~ d e ~ C i e ̂ n c i a s ~ N a t u r a i s ~ e ~ H u m a n a s, ~ U n i v e r s i d a d e ~ F e d e r a l ~ d o ~ A B C ~-~ U F A B C, ~ A v . ~ d o s ~ E s t a d o s ~ 5001, ~}$ \\ CEP 09210-580, Santo André, SP, Brazil \\ 'Departamento de Ciências Biológicas, Universidade Estadual Paulista - UNESP, \\ Av. Luiz Edmundo Carrijo Coube, CEP 17033-360, Bauru, SP, Brazil \\ dDepartamento de Ecologia e Biologia Evolutiva, Universidade Federal de São Carlos - UFSCar, \\ Rodovia Washington Luiz Km 235, São Carlos, SP, Brazil

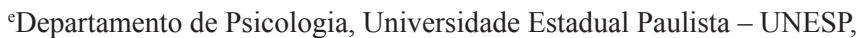 \\ Av. Luiz Edmundo Carrijo Coube, CEP 17033-360, Bauru, SP, Brazil \\ *e-mail: grazivs@gmail.com
}

Received: November 22, 2012 - Accepted: May 20, 2013 - Distributed: August 31, 2014 (With 2 figures)

\begin{abstract}
In New World primates, mixed-species troops have been reported. Here, we analysed the performance of affiliative and agonistic behaviours of Callithrix jacchus and Callithrix penicillata living in mixed groups. For this purpose, we recorded the interaction of the individuals from two groups located in Bauru city, in the state of São Paulo (Brazil). Our data show that in both groups, affiliative behaviours appeared more frequently than agonistic ones. We concluded that there is cohesion inside the mixed-species troops observed. We suggest that a deeper knowledge about the social behaviour of mixed-species troop species certainly may be useful in projects linked with the management of the impact caused by them.
\end{abstract}

Keywords: common marmoset, black-tufted-ear marmoset, social behaviour, hybrid, cohesion, invasive species.

\section{Comportamento social em grupos mistos de Callithrix jacchus e Callithrix penicillata (Primate, Callitrichidae)}

\section{Resumo}

Grupos mistos em espécies de primatas do Novo Mundo têm sido relatados. Aqui, nós avaliamos a emissão de comportamentos afiliativos e agonísticos em grupos mistos formados por Callithrix jacchus e Callithrix penicillata. Para tanto, registramos a interação de dois grupos, localizados no município de Bauru, Estado de São Paulo (Brasil). Nossos dados mostram que nos dois grupos a emissão de comportamentos afiliativos foi maior do que a de comportamentos agonísticos, indicando que há coesão dentro dos grupos mistos estudados. Sugerimos que um conhecimento mais elaborado sobre o comportamento social de grupos mistos pode ser útil em projetos de impactos causados por espécies invasoras.

Palavras-chave: sagui-de-tufo-branco, sagui-de-tufo-preto, comportamento social, híbridos, coesão, espécies invasoras.

\section{Introduction}

The common marmoset, Callithrix jacchus (Linnaeus, 1758), and the black tufted-ear marmosets, Callithrix penicillata (E. Geoffroy, 1812), are considered the two most successful species of the Callithrix genus, if we take into account their large geographic distribution, their high population density, and their efficient capacity for habitat exploration (Stevenson and Rylands, 1988; Miranda and Faria, 2001).
C. jacchus and C. penicillata are primates native to northeast and central Brazil, respectively, that have been introduced to regions outside their native geographical distribution (Ruiz-Miranda et al., 2000; Pinto et al., 2009). Both species are invading and possibly replacing other species in many regions of eastern Brazil, such as in the states of Minas Gerais, Espírito Santo, São Paulo, and Rio de Janeiro (Rylands et al., 2009), reaching the southern by 
the state of Santa Catarina (Santos et al., 2005). In addition, inside the new habitats where they previously not occurred, these species may act as invaders, with potential damage to the preexisting biota, such as by predation of bird's eggs (Alexandrino et al., 2012; Almeida et al., 2013).

One study conducted in the city of Bauru, central-western of the São Paulo state, Brazil, described the presence of both species (de Paula et al., 2005), and reported that in this region, $C$. jacchus and C. penicillata formed mixedspecies troops, with some individuals seeming to be hybrid derivates of the two species. The existence of mixed-species troops of the genus Callithrix has been reported in other studies (Alonso et al., 1987; Modesto and Bergallo, 2008; Sales et al., 2010). A review by Sodaro (1999) emphasises that the successful formation of a mixed-species troops does not guarantee long term advantages and, in comparison to the traditional housing of single species groups of primates, may require higher levels of monitoring to ensure that welfare is not compromised. On the other hand, the associations can be beneficial to both species, as well as to prey, as they help controlling their population (Peres, 1992; Lopes and Ferrari, 1994), predator defense (Peres, 1993), and exploration and defense of larger territories (Garber, 1988; Heymann, 1990).

Studies of interspecific behaviour are important for understanding the nature of associations (Struhsaker, 1981). In this sense, we evaluated the affiliative and agonistic behaviours of two mixed-species troops of C. jacchus and C. penicillata. These behaviours are used in a variety of contexts (Sussman and Garber, 2007), and help to understand the social group structure.

\section{Material and Methods}

\subsection{Study area and subjects}

We conducted the study in the municipal district of Bauru (22 $\left.19^{\prime} \mathrm{S}, 4^{\circ} 04^{\prime} \mathrm{W}\right)$, in the central region of São Paulo state (Brazil). At this location, there are large mixed-species troops of both species, i.e. C. jacchus and C. penicillata, as well as their hybrids, broadly distributed throughout the area (de Paula et al., 2005). Some groups have home range near or inside private properties, and are habituated to human presence. The climate is Cwa
(Koopen's classification), with a moderately rainy, hot, and humid season in the summer, and a dry and cold winter.

We evaluated two mixed groups: (a) Group $1(\mathrm{n}=10)$ : one adult male, two adult females, one sub-adult male and one sub-adult female of C. penicillata and two adult males, one adult female of $C$. jacchus and two infants; (b) Group $2(\mathrm{n}=8)$ : one adult male of $C$. penicillata, two adult females of $C$. jacchus, three juvenile individuals and two infants with intermediate tufts in colour (grey). Each animal within groups was identified by distinctive marks in its morphology, such as scars, size and colour of ear tufts and coat colour pattern.

We estimated individual ages via body size and state of development of sexual organs, in addition to fur characteristics that include the development of ear tufts and white frontal blaze. In this way, adults had fully developed the ear tufts and the sexual organs, whereas sub-adults had incomplete development of them (Decanini and Macedo, 2008).

\subsection{Experimental design}

The two groups are habituated to human presence and, occasionally, received fruits in improvised feeders. Nevertheless, previously to data recording, the two mixed groups of marmosets were monitored in order that they became habituated to our presence. To start the recording of the interactions between the individuals, we place the food in improved feeders. We determined the beginning of interactions when more than one individual arrived at the feeder. After that, we kept the data record during $1 \mathrm{~h}$ per day. We collected data of the all-occurrence (Altmann, 1974) of the affiliative and agonistic behaviours. We considered an individual as a participant in the event when it performed any of the behaviours described in Table 1, directed toward another individual of the group.

The data from both groups were recorded for 10 consecutive days, at morning $(8 \mathrm{~h} 00-10 \mathrm{~h} 00)$ or afternoon periods $(14 \mathrm{~h} 00-16 \mathrm{~h} 00)$, totalling 10 hours per group.

\subsection{Data analysis}

For data analysis, we divided the total number of each registered behaviour by the number of individuals in each group. Within each of them, we compared the total manifestation of affiliative and agonistic behaviours, as well

Table 1. Behaviour during observed period for mixed groups of Callithrix jacchus and Callithrix penicillata.

\begin{tabular}{ll}
\hline \multicolumn{1}{c}{ Behaviour } & \multicolumn{1}{c}{ Definition } \\
$\begin{array}{l}\text { Affiliative } \\
\text { Play }\end{array}$ & $\begin{array}{l}\text { Individual cleaning the fur or skin of another individual using hand or mouth } \\
\text { Individual (mostly juveniles) is engaged in high activity interaction with another individual } \\
\text { involving nonaggressive playful contact }\end{array}$ \\
$\begin{array}{l}\text { Agonistic } \\
\text { Bite }\end{array}$ & $\begin{array}{l}\text { The animal uses teeth to wound parts of the body of another animal } \\
\text { Tight }\end{array}$ \\
$\begin{array}{l}\text { Two marmosets grasp each other and bite each other's head, thorax and abdomen. They tumble, } \\
\text { roll, and often fall onto the floor } \\
\text { Food dispute }\end{array}$ & $\begin{array}{l}\text { Animal walks or runs after chasing another animal } \\
\text { When one individual tries to take food from another animal }\end{array}$ \\
\hline
\end{tabular}


as the rate of each behavioural category via Goodman's proportion test, which considers the dependence between variables (Goodman, 1965). We used $\alpha=0.05$ for all the statistical analyses.

\section{Results}

In both groups, the affiliative behaviours appeared more frequently than agonistic ones (Goodman's test, $\mathrm{p}<0.05$; Figure 1). Figure 2 shows the rate of performance of each expressed behaviour. Within Group 1 (Figure 2a), the affiliative play and allogrooming behaviours appeared in the same rate (Goodman's test, $\mathrm{p}>0.05)$. The frequency of chase was similar to allogrooming (Goodman's test,

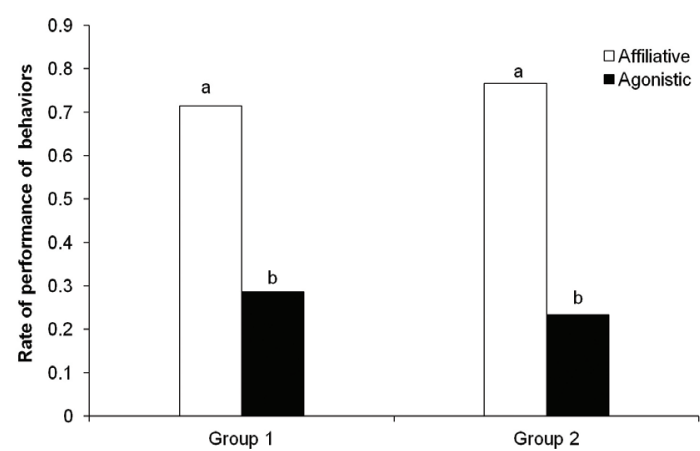

Figure 1. Rates of performance of affiliative and agonistic behaviours in each mixed groups. The total data was divided by the number of individuals per group (Group 1, $\mathrm{n}=10$ and Group 2, n =8). Different letters above the means indicate a significant difference (Goodman's proportion test, $\mathrm{p}<0.05$ ).

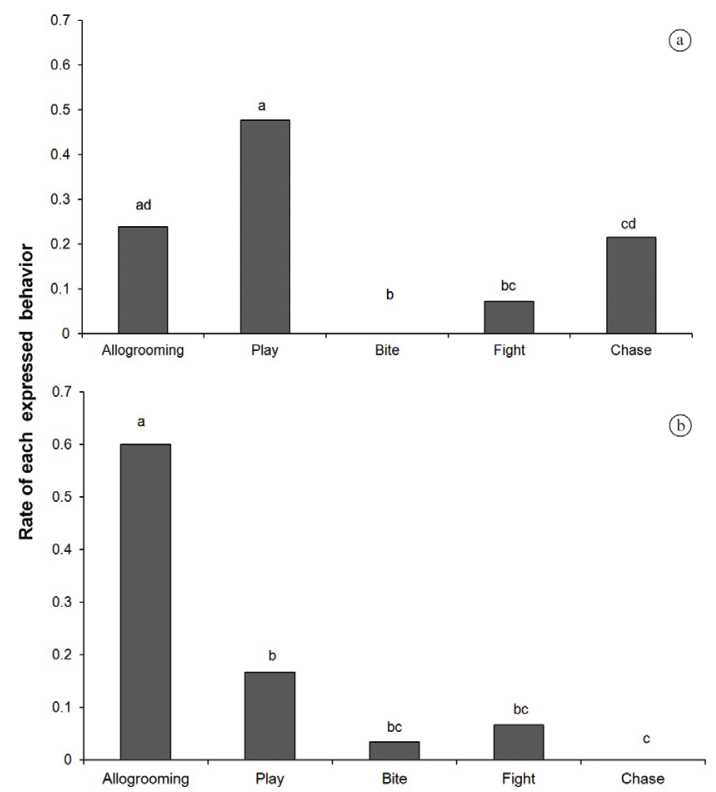

Figure 2. Rate of performance of each behaviour category. (a) Group 1 and (b) Group 2. Different letters above the means indicate a significant difference (Goodman's proportion test, $\mathrm{p}<0.05)$. $p>0.05)$ and the fights and bites (agonistic behaviours) occurred in lower proportion than affiliative. Allogrooming was the kind of behaviour most expressed in Group 2 (Goodman's test, $\mathrm{p}<0.05$; Figure $2 \mathrm{~b}$ ). The play behaviour was expressed in the same rate of bites and fights. There was participation of the infants in all cases of the play behaviour.

\section{Discussion}

Our data show that, in both groups, the affiliative behaviours appeared more frequently than the agonistic ones. This indicates that the pattern of primate social structure is maintained with the coexistence of $C$. jacchus and C. penicillata.

The affiliative behaviours form the basis of associations between individuals in the group (Sussman et al., 2005; Sussman and Garber, 2007). The allogrooming and play were the kinds of affiliative behaviours more frequently observed among the marmosets groups. Allogrooming is a social behaviour common in primates. It is well known that it has a hygienic function by the removal of ectoparasites (Zamma, 2002) and reduction of social tension by the production of endorphins (Schino et al. 1988). It is also linked to group cohesion (Lehmann et al. 2007), and the strengthening of links between individuals (Sánchez-Villagra et al. 1998). Allogrooming can also ensure preferential access to resources (Ventura et al, 2006). In Group 1, the higher rate of play behaviour may be associated with group cohesion, but also could be explained by the presence of infants in it. This behaviour is more frequent among juveniles and infants and certainly helps to improve their social development, motor skills, and encourage learning (Lewis 2000).

The frequency of chase was similar to allogrooming in Group 1. The elevated frequency of chase behaviour in this group may be associated with the presence of more than one adult male. However the marmosets release these agonistic interactions without physical aggression. According to Hinde (1974), when the hierarchy inside the group is well established, individuals with high rank rarely engage in agonistic behaviour. Subordinates usually avoid confrontation, facing away from the simple approach of alpha individuals, thus exerting an active role in the maintenance of hierarchical relationships in social groups.

Our results demonstrate that there is cohesion between the two groups composed of $C$. jacchus and C. penicillata. It is well known that groups of the Callithrix genus are usually structured around a dominant breeding couple with low levels of aggression among members. Wrangham (1980) stated, "Groups have evolved as a result of the benefits of cooperation, between allies competing against others of the same species." This association can bring mutual benefits to the group members, thus keeping the group cohesion can be advantageous. $C$. jacchus and $C$. penicillata vary diet types and the number of species consumed (Rylands and Faria, 1993). The existence of abundant food items in the Brazilian savannah (Cerrado) and the diversity of items 
that are part of the Callithrix diet can also contribute to the stability of the group. It certainly reduces disputes and consequentially increases the links between individuals. When resources are distributed heterogeneously in time and space, feeding competition and group-living might be less costly (Johnson et al., 2002).

On the other hand, such mixed groups may also bring serious concern, as they may increase the chances of success in foraging, and thus the likelihood of predation of eggs and nests, an important factor in the extinction of bird species in the tropics. Almeida et al. (2013) found high levels of predation on artificial nests by these marmosets and their hybrid derivates, suggesting that it may also occur in natural nests.

A deeper knowledge about the social ecology and interactions between these species may be useful in projects linked with the management of the impact caused by them. Furthermore, additional studies in behavioural, ecological, and genetic factors may supply better understanding of the social behaviours of mixed-species troops of C. jacchus and $C$. penicillata, as well as in other groups of primates.

\section{Acknowledgements}

The authors would like to thank Luiz Carlos de Almeida Neto, director of the Jardim Botânico Municipal de Bauru, for his collaboration.

\section{References}

ALEXANDRINO, ER., LUZ, DTA., MAGGIORINI, EV. and FERRAZ, KMPM., 2012. Nest Stolen: the first observation of nest predation by an invasive exotic marmoset (Callithrix penicillata) in an agricultural mosaic. Biota Neotropica, vol. 12, no. 2, p. 211-215. http://dx.doi.org/10.1590/S1676-06032012000200021.

ALMEIDA, MV., LUCINDO, AS., COSTA, TVV. and PAULA, HMG., 2013. Predation on artificial nests by marmosets of the genus Callithrix (Primates, Platyrrhini) in a Cerrado fragment in Southeastern Brazil. Biotemas, vol. 26, no. 1, p. 203-207. http:// dx.doi.org/10.5007/2175-7925.2013v26n1p203.

ALONSO, C., FARIA, DS., LANGGUTH, A. and SANTEE, DF., 1987. Variação da pelagem na área de intergradação entre Callithrix jacchus e Callithrix penicillata. Brazilian Journal of Biology, vol. 47, p. 465-470.

ALTMANN, J., 1974. Observational study of behavior: sampling methods. Behaviour, vol. 49, no. 3, p. 227-267. http://dx.doi. org/10.1163/156853974X00534. PMid:4597405

DECANINI, DR. and MACEDO, R., 2008. Sociality in Callithrix penicillata: II. Individual strategies during intergroup encounters. International Journal of Primatology, vol. 29, no. 3, p. 627-639. http://dx.doi.org/10.1007/s10764-008-9265-6.

GARBER, PA., 1988. Diet, foraging patterns, and resource defense in a mixed species troop of Saguinus mystax and Saguinus fuscicollis in amazonian Peru. Behaviour, vol. 105, no. 1, p. 1834. http://dx.doi.org/10.1163/156853988X00421.

GOODMAN, L., 1965. Simultaneous confidence intervals for multinomial proportions. Technometrics, vol. 7, no. 2, p. 247-254. http://dx.doi.org/10.1080/00401706.1965.10490252.
HINDE, RA., 1974. Biological bases of human social behaviour. Nova York: McGraw-Hill. 462 p.

HEYMANN, EW., 1990. Interspecific relations in a mixed species troop of moustached tamarins, Saguinus mystax, and saddle back tamarins, Saguinus fuscicollis (Platyrrhini: Callitrichidae), at the Rio Blanco, Peruvian Amazonia. American Journal of Primatology, vol. 21, no. 2, p. 115-127. http://dx.doi.org/10.1002/ ajp. 1350210205 .

JOHNSON, DP., KAYS, R., BLACKWELL, PG. and MACDONALD, DW., 2002. Does the resource dispersion hypothesis explain group living? Trends in Ecology \& Evolution, vol. 17, no. 12, p. 563-570. http://dx.doi.org/10.1016/S0169-5347(02)02619-8.

LEHMANN, J., KORSTJENS, AH. and DUNBAR, RIM., 2007. Fission-fusion social system as a strategy for coping with ecological constraints: a primate case. Evolutionary Ecology, vol. 21, no. 5, p. 613-634. http://dx.doi.org/10.1007/s10682-006-9141-9.

LEWIS, KP., 2000. A comparative study of primate play behaviour: implications for the study of cognition. Folia Primatologica, vol. 71, no. 6, p. 417-421. http://dx.doi.org/10.1159/000052740. PMid:11155031

LOPES, MA. and FERRARI, SF., 1994. Foraging behaviour of a tamarin group (Saguinus fuscicollis weddelli) and interactions with marmosets (Callithrix emiliae). International Journal of Primatology, vol. 15, no. 3, p. 373-387. http://dx.doi.org/10.1007/ BF02696099.

MIRANDA, GH. and FARIA, DS., 2001. Ecological aspects of black-pincelled marmoset (Callithrix penicillata) in the cerradão and dense cerrado of the Brazilian central plateau. Brazilian Journal of Biology, vol. 61, no. 3, p. 397-404. http://dx.doi.org/10.1590/ S1519-69842001000300008. PMid:11706566

MODESTO, TC. and BERGALLO, HG., 2008. Ambientes diferentes, diferentes gastos do tempo entre atividades: o caso de dois grupos mistos do exótico Callithrix spp. na Ilha Grande, RJ, Brasil. Neotropical Biology and Conservation, vol. 3, no. 3, p. 112-118. http://dx.doi.org/10.4013/nbc.20083.02.

PAULA, HMG., TAVORA, RS., ALMEIDA, MV., PELEGRINI, LS., SILVA, GV., ZAGANINI, RL. and LUCINDO, AS., 2005. Estudo preliminar da presença de sagüis no município de Bauru (SP), Brasil. Neotropical Primates, vol. 13, no. 3, p. 6-11. http:// dx.doi.org/10.1896/1413-4705.13.3.6.

PERES, CA., 1992. Prey-capture benefits in a mixed-species group of Amazonian tamarins, Saguinus fuscicollis and S. mystax. Behavioral Ecology and Sociobiology, vol. 31, no. 5, p. 339-347. http://dx.doi.org/10.1007/BF00177774.

PERES, CA., 1993. Anti-predation benefits in a mixed-species group of Amazonian tamarins. Folia Primatologica, vol. 61, no. 2, p. 61-76. http://dx.doi.org/10.1159/000156732. PMid:8188122

PINTO, N., LASKY, J., BUENO, R., KEITT, T. and GALETTI, M., 2009. Primate densities in the Brazilian Atlantic Forest: the role of habitat quality and anthropogenic disturbance. In GARBER, PA., ESTRADA, A., BICCA-MARQUES, JC., HEYMANN, EW. and STRIER, KB. (Eds.). South american primates: comparative perspectives in the study of behaviour, ecology and conservation. New York: Springer. p. 413-431. http://dx.doi.org/10.1007/9780-387-78705-3_16.

RUIZ-MIRANDA, CR., AFFONSO, AG., MARTINS, A. and BECK, BB., 2000. Distribuição do sagui (Callithirx jacchus) nas áreas de ocorrência do mico leão dourado no Estado de Rio de Janeiro. Neotropical Primates, vol. 8, no. 3, p. 98-101. 
RYLANDS, AB., COIMBRA-FILHO, AF. and MITTERMEIER, RA., 2009. The Systematics and Distributions of the Marmosets (Callithrix, Callibella, Cebuella, and Mico) and Callimico (Callimico) (Callitrichidae, Primates). In FORD, SM., PORTER, LM. and DAVIS, LC. (Eds.). The smallest anthropoids, developments in primatology: progress and prospects. Chicago: Springer Science. http://dx.doi.org/10.1007/978-1-4419-0293-1_2.

RYLANDS, AB. and FARIA, DS., 1993. Habitats, feeding ecology, and home range size in Genus Callithrix. In RYLANDS, AB. (Ed.). Marmosets and tamarins: systematic, behaviour, and ecology. Oxford: Oxford Science Publications. p. 262-272.

SÁNCHEZ-VILLAGRA, MR., POPE, TR. and SALAS, V., 1998. Relation of intergroup variation in allogrooming to group social structure and ectoparasite loads in red howlers (Alouatta seniculus). International Journal of Primatology, vol. 19, no. 3, p. 473-491. http://dx.doi.org/10.1023/A:1020360422305.

SALES, IS., RUIZ-MIRANDA, CR. and PAULA SANTOS, C., 2010. Helminths found in marmosets (Callithrix penicillata and Callithrixjacchus) introduced to the region of occurrence of golden lion tamarins (Leontopithecusrosalia) in Brazil. Veterinary Parasitology, vol. 171, no. 1-2, p. 123-129. http:// dx.doi.org/10.1016/j.vetpar.2010.02.044. PMid:20378249

SANTOS, CV., LUZ, KP. and SANT'ANNA, FS., 2005. As três espécies de primatas do gênero Callithrix (C. jacchus, C. penicillata e C. geoffroyi) introduzidos na Ilha de Santa Catarina - SC: a importância de pesquisa na implantação do manejo. In Programa e Livro de Resumos do XI Congresso Brasileiro de Primatologia, 2005, Porto Alegre. Porto Alegre: Sociedade Brasileira de Primatologia/PUCRS. p. 59.

SCHINO, G., SCUCCHI, S., MAESTRIPIERI, D. and TURILLAZZI, PG., 1988. Allogrooming as a tension-reduction mechanism: a behavioural approach. American Journal of Primatology, vol. 16, no. 1, p. 43-50. http://dx.doi.org/10.1002/ajp.1350160106.
SODARO, V., 1999. Housing and exhibition of mixed species of Neotropical primates. Brookfield: Chicago Zoological Society.

STEVENSON, MF. and RYLANDS, AB., 1988. The marmoset, genus Callithrix. In MITTERMEIER, RA., RYLANDS, AB., COIMBRA-FILHO, AF. and FONSECA, GAB. (Eds.). Ecology and behaviour of Neotropical Primates. Washington: World Wildlife Fund. p. 131-222.

STRUHSAKER, TT., 1981. Polyspecific associations among tropical rain-forest primates. Zeitschrift für Tierpsychologie, vol. 57, no. 3-4, p. 268-304. http://dx.doi.org/10.1111/j.1439-0310.1981. tb01928.x.

SUSSMAN, RW., GARBER, PA. and CHEVERUD, JM., 2005. Importance of cooperation and affiliation in the evolution of primate sociality. American Journal of Physical Anthropology, vol. 128, no. 1, p. 84-97. http://dx.doi.org/10.1002/ajpa.20196. PMid:15778981

SUSSMAN, RW. and GARBER, PA., 2007. Cooperation and competition in primate social interactions. In CAMPBELL, CJ., FUENTES, A., MACKINNON, KC., PANGER, M. and BEARDER, SK. (Eds.). Primates in perspective. New York: Oxford University Press. p. 636-651.

VENTURA, R., MAJOLO, B., KOYAMA, NF., HARDIE, S. and SCHINO, G., 2006. Reciprocation and interchange in wild Japanese macaques: grooming, cofeeding, and agonistic support. American Journal of Primatology, vol. 68, no. 12, p. 1138-1149. http://dx.doi.org/10.1002/ajp.20314. PMid:17096423

WRANGHAM, RW., 1980. An ecological model of femalebonded primate groups. Behaviour, vol. 75, no. 3, p. 262-300. http://dx.doi.org/10.1163/156853980X00447.

ZAMMA, K., 2002. Grooming site preferences determined by lice infection among Japanese macaques in Arashiyama. Primates, vol. 43, no. 1, p. 41-49. http://dx.doi.org/10.1007/BF02629575. PMid:12091746 